\title{
Editorial
}

\section{Climate change: Assessing effects on health and wealth of populations}

Journal of Public Health Policy (20I5) 36, 38I-383. doi:I0.I057/jphp.201 5.26; published online 20 August 2015

Can the health consequences of climate change be at the center of discussions at this year's climate summit in Paris? Very possibly. Pope Francis' encyclical letter and The Lancet's excellent report on the topic give us hope. ${ }^{\mathrm{I}, 2}$ Now the World Federation of Public Health Associations (whose Federation's Pages we publish in JPHP) is preparing to participate in the twenty-first Conference of the Parties, United Nations Framework Convention on Climate Change. The Federation and its Environmental Health Working Group have developed a strategy to put population health front and center in the Paris discussions. We commend them.

Less clear is whether the discussions will go beyond the direct health effects of climate change and explore the health and wealth consequences of efforts to control it and adapt to it.

Public health scholars have concluded that environmental factors both the physical and social environments - affect health. They have imported the word determinant from mathematics to describe these causal relationships. They have also chosen the adjective 'social', although we do not think they mean to exclude physical exposures like housing and workplaces. And since the Report of the WHO Commission on the Social Determinants of Health, ${ }^{3}$ our colleagues in public health are more attentive to what influences the health of populations. Wealth and income are high on the list. This is a salutary trend, as it constitutes a countervailing force against the long dominant tendency to attribute improvements in health to medical care effectiveness, and failure to improve health to medical care deficiencies - surely a very narrow view.

A more recent book, Thomas Piketty's Le capital au XXI ${ }^{e}$ siècle, ${ }^{4}$ (Capital in the Twenty-First Century) has presented a new analytic 
approach to inequalities in income and wealth. He describes how over the last two centuries, as income flowed to the richest people, wealth in industrial societies has become concentrated in a very small minority increasing wealth inequality. There was one brief period, from the I940s to the I980s, where wealth inequality declined, but Piketty suggests that this was an historical aberration, not the long-term trend. He predicts increasing wealth inequality in the twenty-first century, a feature of capitalist economies, unless we do something about it. And with wealth inequality the world gets health inequality.

What is the role of climate change and how does it impinge on health and wealth inequality on our planet?

Since the Earth Summit in I992, and adoption of the Kyoto Protocol to the United Nations Framework Convention on Climate Change in I997, a series of international conferences and their declarations have focused increasingly on reducing poverty, plus promoting job growth, clean energy, and fairer, sustainable use of resources. Coping with climate changes has become a pervasive theme globally.

At the risk of over-simplification, one can place responses to climate change in two categories:

- Efforts to reduce the causes, particularly greenhouse gas emissions and

- Efforts to adapt to the effects of climate change.

Both kinds of response will almost certainly have consequences for health and wealth on the planet. They may preserve inequities or create greater ones. Or, if crafted well, they might improve health and wealth equality.

The next summit, the twenty-first Conference of the Parties on Climate Change, will take place in Paris in December 2015. Signatories will offer and be offered many proposals for how to cope with climate change. To reduce emissions of greenhouse gases, interventions will surely target electricity generation to make it cleaner and more efficient (plus transport, buildings, and agriculture). To live with the consequences of climate change, participants will explore an even wider range of prescriptions - from dikes to new crop varieties.

To drive a focus on health, the World Federation of Public Health Associations (WFPHA) wants each of its member national associations to assess its government's Climate Change Action Plan for the Paris

382 () 2015 Macmillan Publishers Ltd. or 97-5897 Journal of Public Health Policy Vol. 36, 4, 38I-383 
summit with regard to the health consequences of climate change and responses to them. Which countries have proposed particularly creative approaches? Each national association will be asked to complete a questionnaire. The results, if every association responds, will constitute the most complete picture of efforts to prevent and remediate the health consequences of climate change.

We might ask an even more difficult question. With growing concern about health and wealth inequalities, would it be possible to assess all of the climate change proposals and policies brought to the Paris meeting for their effects on the distribution of health and wealth? Here we mean not just between countries, but within countries as well.

There is a precedent for this kind of assessment. In many countries, laws require that new policies and projects be assessed for their projected environmental consequences. In the United States, for example, there are laws requiring 'environmental impact assessments.' The entity that proposes a policy or project must offer a publicly available assessment of its environmental effects.

As the world puts together the Paris summit, we suggest that leaders endorse the WFPHA efforts and consider how to require that every proposed policy, investment, or intervention to cope with climate change include careful health and wealth impact assessments.

\section{References and Notes}

I. Encyclical letter LAUDATO SI of The Holy Father Francis on care for our Common Home, http://w2.vatican.va/content/dam/francesco/pdf/encyclicals/documents/papa-francesCO_20I 50524_enciclica-laudato-si_en.pdf, accessed 20 July 2015.

2. The Lancet. (2015) Health and climate change: policy responses to protect public health, http:// www.thelancet.com/commissions/climate-change\#Jun23, accessed 23 June 2015.

3. The WHO Commission on the Social Determinants of Health. (2008) Closing the gap in a generation: Health equity through action on the social determinants of health, http://www.who. int/social_determinants/thecommission/finalreport/en/.

4. Piketty, T. (2013) Le capital au XXI siècle (Capital in the Twenty-First Century). Paris, France: Éditions du Seuil.

Anthony Robbins

Co-Editor

E-mail: anthony.robbins@tufts.edu 